\title{
Early ecological research on rodents in New Zealand, 1946-1976: personal recollections
}

\author{
Rowley Taylor \\ 13 Templemore Drive, Richmond, Nelson 7020 \\ (Email: rowley.pat@xtra.co.nz)
}

Published online: 12 January 2016

\begin{abstract}
Ecological research into rodents in New Zealand commenced in the late 1940s with the creation of the Animal Ecology Section, Department of Scientific and Industrial Research (DSIR). Field surveys of rodents were backed by study skins and skeletal material. Supplemented by specimens from the Wildlife Service and the public, these accrued over the next 45 years laying the foundation for our present knowledge of rodent distribution. In 1951, J. S. Watson joined the DSIR from the Bureau of Animal Population, Oxford, and brought much needed experience in rodent biology and control. Publications followed on the identification, distribution and interrelations of rodents with native fauna, but such research waned temporarily following his death in 1959. In the early 1960s, Forest \& Bird Protection Society members and the Wildlife Service used pre-packaged warfarin baits to control rats on small islands in the Hauraki Gulf, but the full significance of these operations was not understood for many years, it being widely held that complete extermination of rats was impossible. The 1964 ship rat invasion of Big South Cape Island and subsequent extinctions of endemic birds and bats sent shock waves through conservation circles and led to an increased interest in the ecology of rodents and their impact on native species. The mid-1960s saw the start of intensive research into Norway and ship rats. The next decade was one of intensified research culminating in the historic 1976 Department of Lands and Survey symposium on the Ecology and Control of Rodents in New Zealand Nature Reserves, further boosting interest in rodent distribution, food habits, reproduction, dispersal ability, interspecific competition, interactions with other species, and the steady development of eradication techniques now employed worldwide.
\end{abstract}

Key words: Rattus rattus, Rattus norvegicus, Rattus exulans, Mus musculus, eradication, conservation, history.

\section{Introduction}

In celebrating 50 years of rodent eradications in New Zealand we acknowledge the amazing progress made from very small beginnings. We should also remember that these outstanding technical achievements owe much to basic research — studies of the distribution, biology, behaviour and methods of detection of rats and mice in New Zealand's unique plant and animal communities. Such ecological research has progressed exponentially, and here I will attempt to outline from personal experience the first 30 years of its relatively short New Zealand history.

My interest in rodents was first roused in 1948 when as a 16-year-old I started holiday work at the Animal Ecology Section of the Department of Scientific and Industrial Research (DSIR) in Wellington. Two years earlier, in 1946, DSIR had appointed Dr Kazimierz Wodzicki (Kazio to his friends), a Second World War exile from Poland and formerly a professor of anatomy and biology, to survey the status of New Zealand's introduced mammals (Fleming \& Bull 1988). The most recent previous review had been by Thomson (1922) thirty years earlier. Wodzicki obtained his data from questionnaires, interviews and collecting specimens during journeys throughout the country.

In those days I was interested in maps, the outdoors, shooting rabbits, and identifying birds; and met Wodzicki through my father (who was then Assistant Director of DSIR's Soil Bureau). I worked with Wodzicki's group during all school holidays from 1948 until early 1950 (when I joined its permanent staff) and gained skills in organising camping trips, recognising wildlife, collecting specimens and surveying field areas.

By May 1948, Wodzicki's Wildlife Research Unit had a fulltime staff of three, and was renamed the "Animal Ecology Section" to avoid confusion with the Wildlife Division of the Department of Internal Affairs. I remember the strange name change, for the word "ecology" was then unknown to the New Zealand public and, outside of narrow academic circles, was not widely understood for several more decades.

\section{Which rodents?}

During 1948 and 1949, I was involved in field trips to several North and South Island locations (often on farm land and State Forests), where we trapped for rodents and carried out other mammal observations, particularly on wild rabbits. The results of the initial survey were published as DSIR Bulletin Introduced Mammals of New Zealand (Wodzicki 1950). Before this survey there was much confusion as to just which mammals had survived introduction into the wild. Particularly, which species of rodents, mustelids, deer and wallabies were still extant in New Zealand.

Although there are many references to rodents in early New Zealand literature, it was often hard to interpret the species involved. Use of common names such as "English rats", "water rats", "brown rats", "bush rats" and "field mice" led to much confusion. Sometimes the reported presence of "rats" could be shown on deeper analysis to really mean "mice", for example, on the Auckland Islands (Raynal 1875; Greig 1886) and on Coal Island, Fiordland (Anon. 1890).

During the Second World War (1939-45), scientist- 
coastwatchers, including Jack Sorensen (1949, 1951) had identified the presence of kiore and Norway rats on Raoul Island, Norway rats on Campbell, and house mice on the Auckland Islands. So, by 1950 we knew we were dealing with at least four species of rodent: the kiore (Rattus exulans); the Norway rat (Rattus norvegicus); the ship rat (Rattus rattus with its three colour morphs); and the house mouse (Mus musculus).

\section{Surveys and distributions}

Before 1948, there were doubts (Thomson 1922) whether kiore were still extant in New Zealand, except on Hen Island where Edgar Stead (1937) had found them in 1933. In 1947 and 1949, during DSIR expeditions (Wodzicki \& Robertson 1959) some were collected from White Island (Figure 1), and attempts were then made to obtain specimens from other likely places, particularly on off-shore islands.

Together with specimens collected earlier, these formed the basis of what grew into a very valuable and substantial reference collection of small-mammal skins and skeletal material, much later gifted to The Museum of New Zealand/ Te Papa when DSIR was disestablished in 1991, and drawn on extensively for the review Distribution of alien mammals on New Zealand islands (Atkinson \& Taylor 1992).

From the start, specimens were sent in by farmers, seed and grain store managers, possum trappers, deerstalkers, museum biologists, school teachers, council workers, lighthouse keepers, foresters and Acclimatisation Society rangers, amongst others. Long-term cooperation with the Wildlife Division of
Internal Affairs began in 1947 with rats collected by Les Pracy from the Orongorongo Valley. Other early collectors from the Wildlife Division were Ralph Kean, Logan Bell, Bill Axbey and Brian Bell.

In 1949, Wodzicki and Peter Bull took part in the New Zealand-American Fiordland Expedition (Figure 2), trapping for small mammals in Caswell and George Sounds. Here, very surprisingly, only one mouse and two stoats (Mustela erminea) were caught in 386 trap-nights using a variety of break-back rat and mouse traps and steel gin traps. Frank Woodrow, an experienced Canadian trapper from the Wildlife Division, was also along and set further traps in Caswell Sound and more on Resolution Island, again finding stoats but no rats (Kean 1951; Wodzicki \& Bull 1951).

During this three month-long expedition the rare presence of rats was reported only from Milford, George and Doubtful Sounds, which we thought somewhat strange, considering previous reports by Reischek (1888) and Henry (1901) of their abundance in Western Fiordland only fifty years earlier. It was many years later that we came to understand how the introduction of mustelids had influenced these changes (Taylor 1978).

In January 1950, I accompanied Charles Wright (of DSIR's Soil Bureau), Peter Bull and others on the first of a series of ecological surveys (Bull 1952) in the region lying to the west of Lake Taupo (Figure 3). In those days, the country from the road between Tokaanu and Taumarunui north to Tihoi, and west to the summit of the Hauhangaroa Range was all

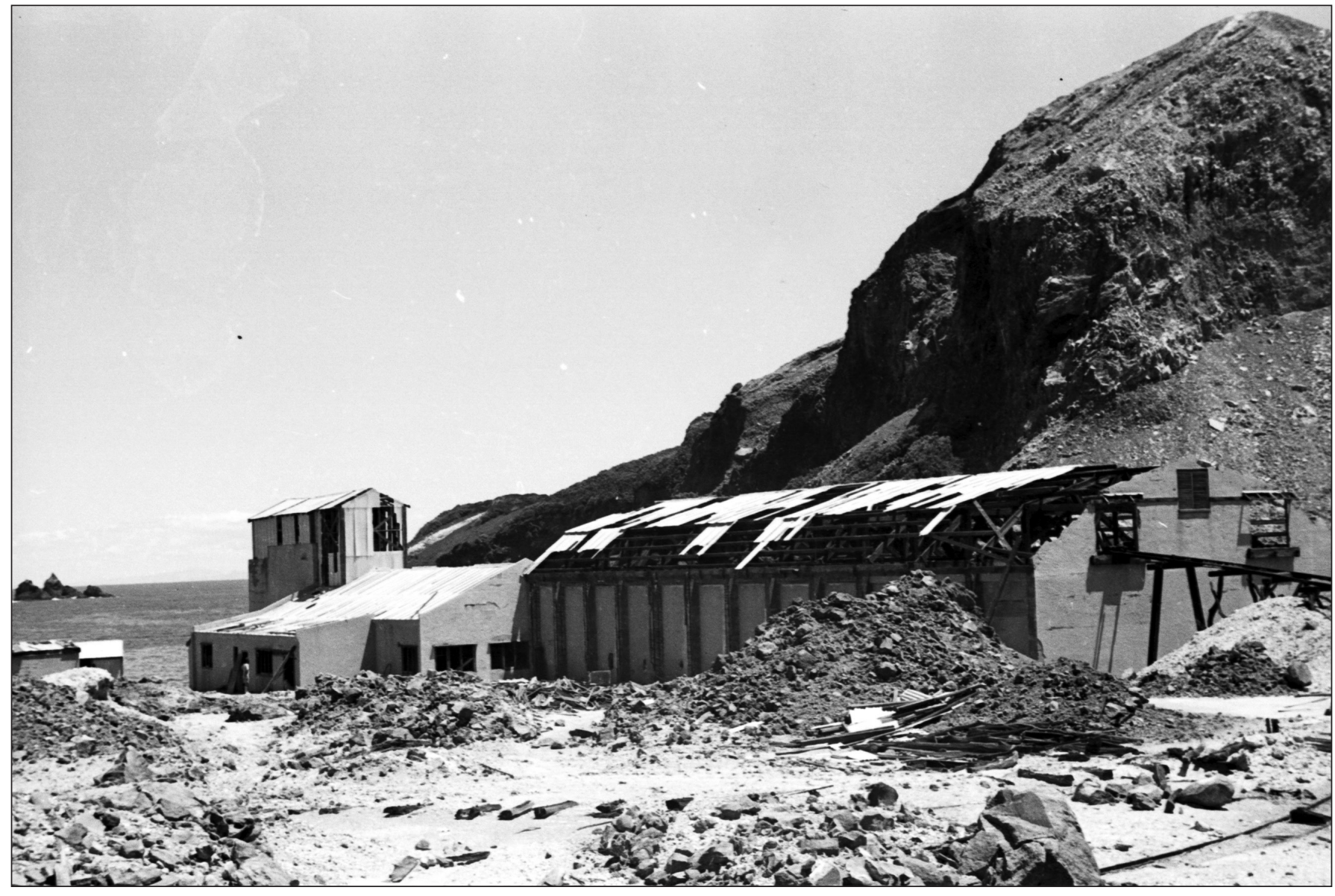

Figure 1. The abandoned sulphur factory on White Island, November 1949, where Wodzicki trapped and identified kiore. Photo by Kazimierz Wodzicki. 


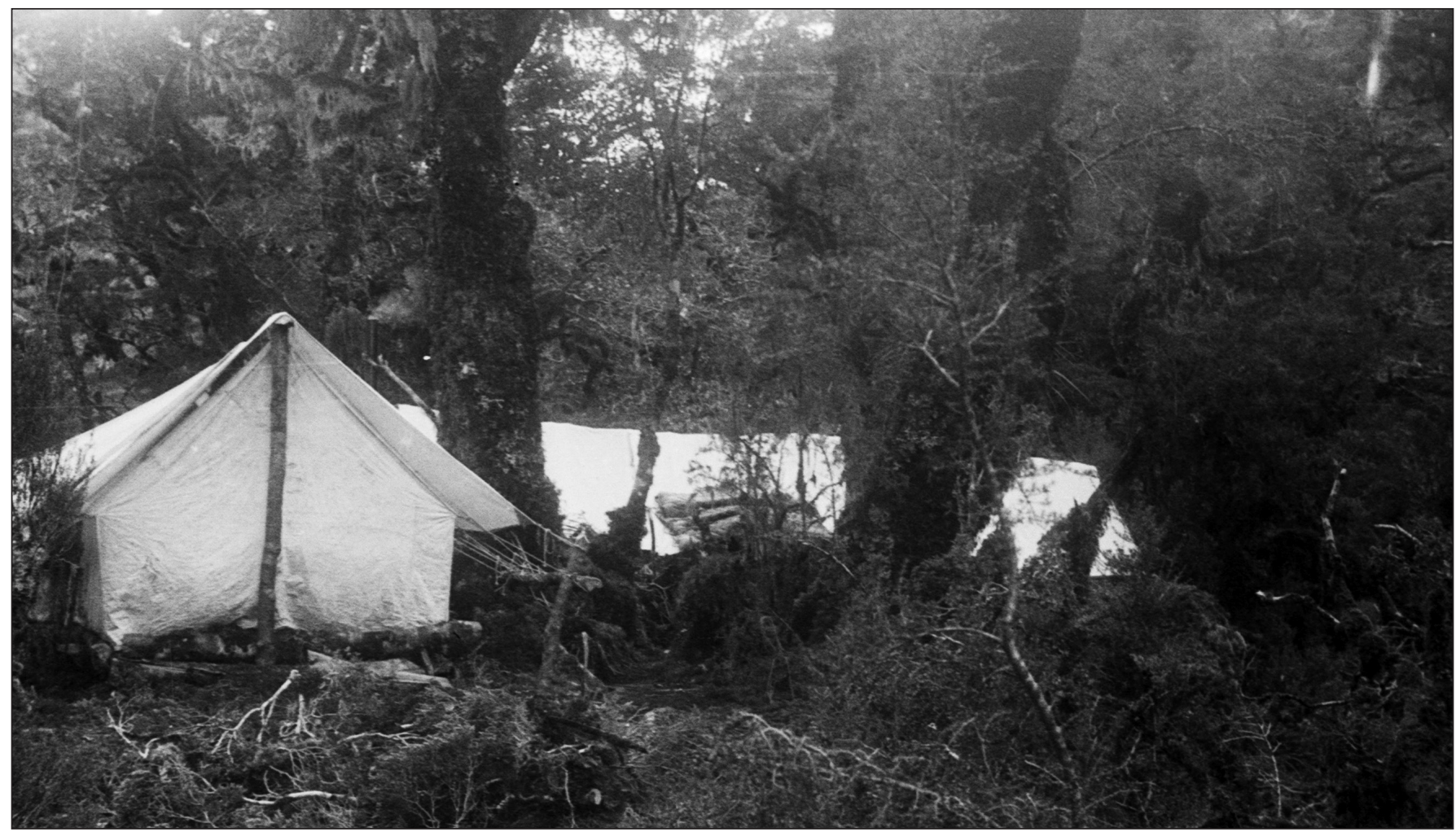

Figure 2. Camp in lowland forest behind Caswell Sound during the New Zealand-American Fiordland Expedition, February-April 1949. Hereabouts, Bull and Wodzicki trapped for small mammals catching only one mouse and two stoats, but no rats in 386 trap-nights. Photo by Kazimierz Wodzicki.

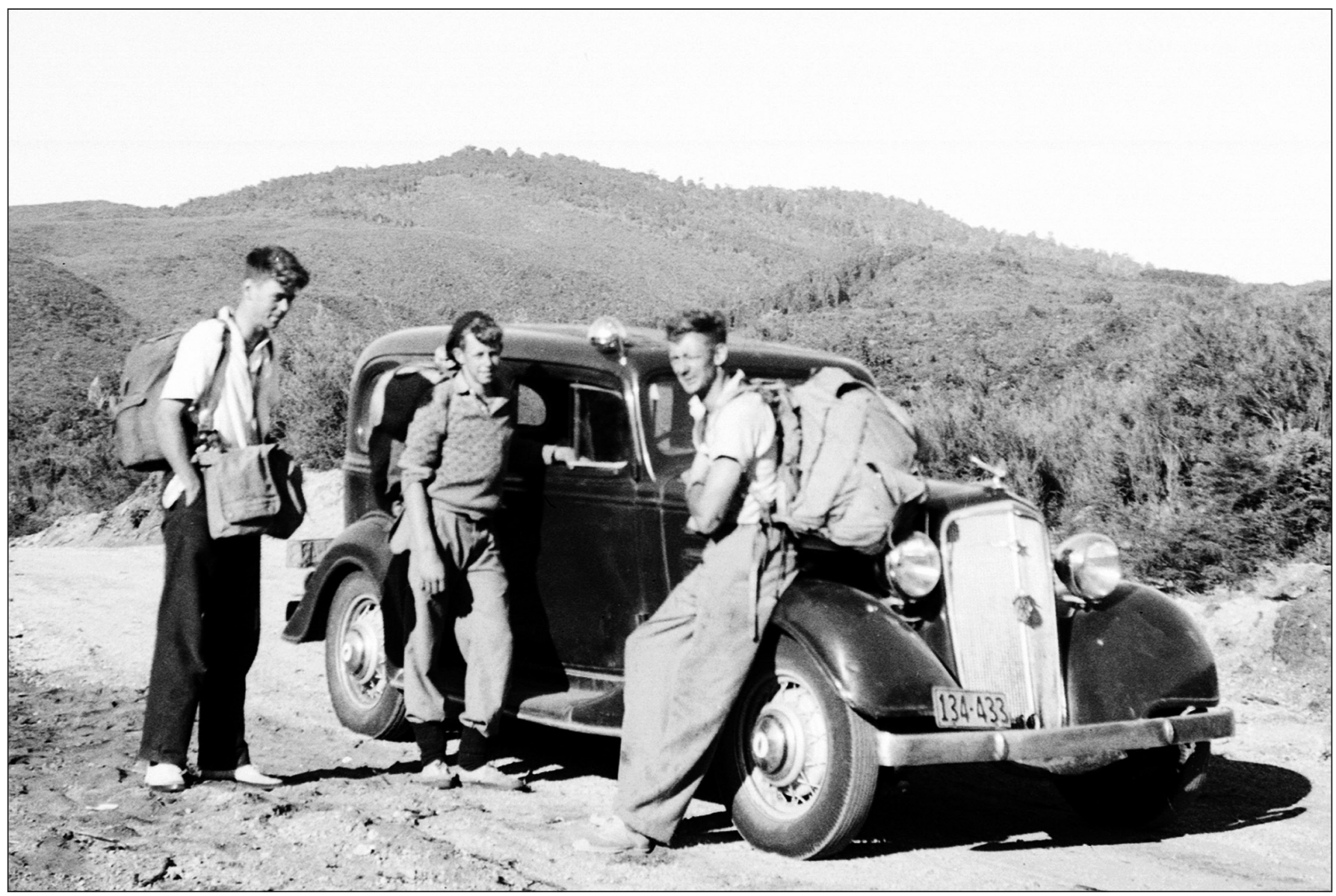

Figure 3. Field party on the "Hydro Track" west of Lake Taupo during the initial DSIR Ecological survey of the region, January 1950 From left, Rowley Taylor, Keith Lawrence and Charles Wright. Photo by Peter Bull. 
scrub, open frost flats and native bush, with only a few mill roads and a newly bulldozed track for the soon to be erected transmission lines. Many rodent traps were set (Bull 1950a, 1950b) and we learnt much of the distribution and habitat niches of Norway rats, ship rats and mice.

The following summer I was on another expedition with Wright; a soil, bird and mammal survey of central Stewart Island (Taylor 1951). There we gained further insight into rodent behaviour, and the species' preferred niches. All the huts we used were also used by rats, and specimens were trapped, measured, and preserved. They included kiore but, surprisingly no mice. On Native Island we caught only ship rats, but neighbouring Ulva Island reportedly had Norway rats, and the adjacent mainland had all three species.

On Stewart Island (without mustelids) Norway rats were almost everywhere, even on top of Table Hill, whereas in the dry pumice land west of Lake Taupo, we had found them confined to the lake edge or along stream banks. Could safe refuge from stoat predation, rather than a dislike of arid habitats, be involved? This finding opened our eyes to the possibility of inter-specific exclusion, though it was another 24 years before I, personally, was able to again follow this lead and publish on What limits Kiore distribution in New Zealand (Taylor 1975a).

This exemplifies the importance of island studies in ecology, where the presence of various combinations of species enables their interactions and individual impacts to be more easily understood.

During the first 10 years of Animal Ecology Section's existence, the major research effort was on rabbit populations and the few staff had little time to devote to rodents. In 1954, I was on two expeditions to the subantarctic Auckland Islands (Bull 1954; Falla 1954) - the first with Bull and the second with Wodzicki- to study wild rabbit populations originally released there as food for castaways. Mice and their sign were obvious in the wartime coastwatchers huts at Ranui Cove on the main island. While camped on Enderby and Rose Islands we also trapped for rodents, catching mice on Enderby where their sign was obvious in the old boatshed, but they were absent on Rose Island, where castaway relics in the shed included packets of candles untouched by mice.

The lesson from this, and earlier experience on Stewart Island, was that rodents will reveal their presence by using shelter and food provided by humans. Much later we were able to exploit this "weakness" by devising "rat motels" (Russell et al. 2008). These "rat motels" are boxes providing secure shelter and food (such as dog biscuits) as a way of detecting the presence of rodents. They were first tested by the Ecology Division at Nelson Lakes National Park in the 1960 s, but it was only after the eradication of ship rats from Tawhitinui Island (Taylor 1984) that they were deployed to detect re-infestation of an island. From 1962, I was engaged in red deer research in the South Island mountains, and learnt more of the altitudinal distribution of rats and mice. In southern beech forests, Norway rats were seldom present; ship rats were abundant only in seed years and always rare at high altitudes (never above the bushline). Mice were everywhere, even in winter (Taylor \& Flux 1965).

\section{J S Watson's legacy}

Scientific study to assist food production during the Second World War (1939-45) gave a tremendous boost to rat research in the United Kingdom (Chitty \& Southern 1954). For almost the first time there were many studies published on rodent behaviour outside the traditional laboratory environment, and these findings and skills soon spilt over to New Zealand. In 1951, J.S. (Sharon) Watson joined the Animal Ecology Section from the Bureau of Animal Population at Oxford where he had been working on rat biology and pest control in the London Docks, the Middle East and Cyprus (Watson 1951). Although employed by DSIR to study the reproduction of wild rabbits, his rodent expertise was immediately of great benefit to the Animal Ecology Section. He looked through our collections and found at least two kiore that had been misidentified, one collected from Doubtful Sound in 1949 by Graham Turbott, and another that I had trapped on Stewart Island. This resulted in me very quickly learning the importance of accurately identifying and sexing all rats handled. It disappoints me that even today many dedicated pest trappers do not recognise and record one species of rat from another-to them, as it once was for me, "a rat is a rat".

Watson's first paper on New Zealand rats was on the differences between the species and was part of a series on Aliens in the Forest published in Forest \& Bird (Watson 1953). There followed five other publications on rodents (Watson 1956, 1959, 1961a, 1961b; Riney et al. 1959); including one on the distribution of kiore in New Zealand (Watson 1956) and the pioneer Rats in New Zealand; a problem of interspecific competition (Watson 1961b). In 1956-57, I assisted him on trips to South Westland to investigate, at the request of the NZ Forest Service, the impact of rodents on the regeneration of podocarp forests. In 1958 he found that kiore still existed with Norway rats on Kapiti Island. He also retained an interest in urban rats and was in contact with official rat-catchers in several of our main cities and ports.

I have no doubt that the study of rodent ecology and control in New Zealand would have advanced much more rapidly but for Watson's untimely death in August 1959. At that stage his knowledge of rodent biology and control was far in advance of anyone else in the country and all in Animal Ecology Section were learning from him. His final project was a study of the predator-prey relationships between rats, feral cats and birds on Little Barrier Island. Some of its preliminary findings were later published (Marshall 1961).

\section{Conservation impacts and rodent control}

The potential threat that European rats posed to conservation on island refuges had been pointed out for many years; by Edgar Stead, Bob Wilson, Guthrie-Smith and Lance Richdale amongst others, we all nodded and agreed, but no practical precautions were taken. Guthrie-Smith's (1936) warning was in fact specific to the Big South Cape Islands (southern Stewart Island), and very direct: "should rats obtain a footing, farewell to Snipe, Robin, Bush Wren and Saddleback, none of which species are able to adapt themselves to novel conditions. As on the mainland these four interesting breeds will disappear".

In 1959, Forest and Bird Society members from Waiheke Island led by Alistair McDonald and assisted by Don Merton started using pre-packaged warfarin baits to control rat damage to nesting white-faced storm petrels (Pelagodroma marina) on Maria Island, Hauraki Gulf, but the success and full significance of the operation was not understood for many years; it then being widely held that the eradication of rats from islands was impossible (Thomas \& Taylor 2002; Stolzenburg 2011).

The 1964 invasion of the Big South Cape Islands by ship rats led to the extinction of endemic birds and bats, and sent shock waves through conservation circles (Bell 1978; Bell et al. 2016). Rodent poisoning by the Wildlife Service followed, but this was a control operation rather than an attempt at 
eradication. Animal Ecology Division was unable to help, then having staff with only a part-time interest in rats.

During the early 1960s Tony Beveridge (1964) of the New Zealand Forest Service studied the inter-relations of rats and seedfall in the Pouakani podocarp forest, and in 1964-65, Beveridge and Mike Daniel $(1965,1966)$ studied the ecology and control of Norway rats on Mokoia Island, Lake Rotorua. In those same years, Tom Choate of Otago University published on small mammal surveys on Stewart Island (Choate \& Gibbs 1964), at Jackson's Bay (Choate 1965a), at Thompson Sound and Secretary Island, Western Fiordland (Choate 1965b) and in the Monowai-Grebe River region (Choate 1967). Ornithological Society of New Zealand and Wildlife Service expeditions to Macauley, Raoul and adjacent islets in 1966 and 1967 (Merton 1968, 1970) widened our understanding of the distribution and impact of introduced rodents in the Kermadec Group.

Kazio Wodzicki retired from DSIR in 1965 and continued for twenty years to publish on the ecology and control of rats, particularly on kiore in the South Pacific (e.g. Wodzicki 1969; Wodzicki \& Taylor 1984). Ford-Robertson and Bull (1966) recorded parasites from kiore collected at Little Barrier and Hen Islands. In 1966, Mike Daniel joined the Ecology Division, and commenced research on rats in the Orongorongo Valley and on Kapiti Island (Daniel 1969). In 1968 Lindsay Best of Canterbury University completed a study of the foods and fertility of ship rats from two forest areas in the South Island, Banks Peninsula and North Westland (Best 1969, 1973). In January-February 1970, I took part in an expedition to Antipodes Island and saw how mouse populations can reach huge densities when food (in this case Carex and tussock seed) is in abundance (Taylor 1970).

\section{Irruptions}

One aspect widely dealt with in early New Zealand writing was periodic rat and mouse "plagues". These irregular irruptions, which still actively concern rodent ecologists and conservation managers, were recognised as far back as the 1880s to follow very heavy seeding in southern beech (Nothofagus) forests (Meeson 1885; Reischek 1888; Rutland 1890). One time or another, they have clearly involved combinations of kiore, ship rats and mice. Really massive rodent plagues rarely happen, perhaps every 20 to 30 years, when mast seeding of all three Nothofagus species is in phase. In 1972, I obtained from Mr P J O'Regan (whose family had farmed near Inangahua Landing since 1872) details of past rodent plagues in that district. It seems that in the Inangahua/Murchison area major irruptions occurred in c.1880, 1915, 1935, 1971 and $1999(\mathrm{P}$ J O' Regan pers. comm.; pers. obs.). Smaller irruptions, like the 2014 one in the northern South Island, happen more often (Wilson et al. 1998; pers. obs.).

During the 1971 rodent irruption, Bruce Thomas and I were in the field in the Nelson Lakes area and witnessed the event first hand. On windy days during the previous summer smoke-like clouds of beech pollen had been seen blowing about the mountain slopes, foretelling of a mast year to come. The surge of rat numbers was at first reflected by Nelson Lakes National Park stoat-trapping lines in July 1971, with up to five rats a day being caught in 14 Fenn traps set in red beech forest near the source of the Buller River.

Abnormal behaviour of both rats and mice became obvious in the second week of November when numbers were seen alive in the bush or on tramping tracks during daytime, and running across highways at night. Hundreds of dead rats were reported from the shoreline or floating in Lakes Rotoroa and Rotoiti. This coincided with the germination of most red and mountain beech seed in the region. Seemingly, with the seedbank suddenly gone rodents had to search for new foods, or starve. Our autopsies suggested many were resorting to honeydew. At the rural Gowan Bridge store (near Lake Rotoroa) locals started buying rat poison in mid-October, sales peaked in mid-November, but poison was still selling well in December and there were still more rats than usual around in March 1972. This rodent "plague" occurred over a wide area including the Lewis Pass, Maruia Valley, Inangahua, Buller Gorge and Nelson Lakes (BW Thomas pers. comm.; PJ O'Regan pers. comm.; pers. obs.) - it was by far the largest I have seen.

During visits to Stewart Island and the West Coast Sounds in the 1870s Thomson (1922) was struck by the abundance of Norway rats "in regions uninhabited and almost unvisited by man". On a wide stretch of mile-long shore in Patterson Inlet, Stewart Island, he found "the whole beach alive with rats which were feeding on the shellfish and stranded animals which the tide had left exposed". When alarmed they ran to the shelter of the bush, "they were literally in hundreds". Such early immense numbers of Norway rats, also reported from Fiordland by Reischek (1888) and Henry (1901), were probably not the result of periodic heavy forest masting. Rather, they likely arose from an abundance of previously unexploited resources and a lack of competition and predation from later arriving ship rats and (in Fiordland) mustelids.

\section{Later developments}

The years 1971 to 1976 were ones of intensified rodent research in New Zealand, stimulated to some extent by the response of rat and mouse populations to the massive 1971 fruiting in both North and South Island forests (Daniel 1978; pers. obs.). A major Ecology Division study continued on the bionomics and diet of ship rats in the Orongorongo Valley near Wellington (Daniel 1972, 1973). Interest also increased in rodent parasites and the role of rats and mice in maintaining and spreading disease (e.g. Brockie 1976; Gibson 1972). Numerous island surveys expanded our knowledge of rodent distribution in northern New Zealand (e.g. Bettesworth 1972; Bettesworth \& Anderson 1972), Fiordland (Thomas 1975), Stewart Island (Taylor 1975a) and at the Auckland Islands (Taylor 1975b).

A further important impetus to research was Ian Atkinson's (1973) reconstruction of the Spread of the Ship Rat in New Zealand. Then, with studies of the effects of rats on lizards (Whitaker 1973), tuatara (Crook 1973) and petrels (Imber 1975), we began to really sense the impact of introduced rodents on the New Zealand environment. This culminated in the historic 1976 symposium on the Ecology and Control of Rodents in New Zealand Nature Reserves (Dingwall et al. 1978) and further boosted research into rodent distribution, food habits, reproduction, dispersal ability, interspecific competition, interactions with other species and the steady development of eradication techniques now employed worldwide.

Finally, when dealing with rats it pays to remember there are no cast-iron rules. Rodents are very clever animals, and the key to their control and eradication is to understand their life strategies and identify and exploit weak points. In this respect we have made amazing advances in the last 50 years - due mainly to a better understanding of rodent populations and behaviour, the development of second generation anticoagulant poisons, and improved baiting techniques. I have learned never to be surprised. There are always exceptions. How often have we been told: "Norway rats are poor climbers", 
or "ship rats don't nest in burrows"? A life time of experience tells me otherwise.

\section{Acknowledgments}

I thank Bruce Thomas for help with published and unpublished references and discussion, and two anonymous reviewers for valuable comments on the manuscript.

\section{References}

Anon. 1890. The Coal Island gold-field. Otago Daily Times. 5 September 1890. Pp. 3.

Atkinson IAE 1973. Spread of the ship rat (Rattus r. rattus L) in New Zealand. Journal of the Royal Society of New Zealand 3: 457-492.

Atkinson IAE, Taylor RH 1992. Distribution of alien mammals on New Zealand Islands (second edition). Contract report No.92/59. Lower Hutt, New Zealand, Department of Scientific and Industrial Research, DSIR Land Resources.

Bell BD 1978. The Big South Cape Islands rat irruption. In: Dingwall PR, Atkinson IAE, Hay C eds The ecology and control of rodents in New Zealand nature reserves. Information Series No. 4. Wellington, New Zealand, Department of Lands and Survey. Pp. 33-40.

Bell EA, Bell BD, Merton DV 2016. The legacy of Big South Cape: rat irruption to rat eradication. New Zealand Journal of Ecology 40: 212-218.

Best LW 1969. Food of the roof rat Rattus rattus rattus (L), in two forest areas in New Zealand. New Zealand Journal of Science 12: 258-267.

Best LW 1973. Breeding season and fertility of the roof rat Rattus rattus rattus, in two forest areas in New Zealand. New Zealand Journal of Science 16: 161-170.

Bettesworth DJ 1972. Rattus exulans on Red Mercury Island. Tane 18: 117-118.

Bettesworth DJ,Anderson GRV 1972. Diet of Rattus norvegicus on Whale Island, Bay of Plenty, New Zealand. Tane 18: 189-195.

Beverage AE 1964. Dispersal and destruction of seed in central North Island podocarp forests. Proceedings of the New Zealand Ecological Society 11: 48-55.

Beveridge AE, Daniel MJ 1965. Observations on a high population of brown rats (Rattus norvegicus Berk.1767) on Mokoia Island, Lake Rotorua. New Zealand Journal of Science 8: 174-187.

Beveridge AE, Daniel MJ 1966. A field trial of a new rat poison, compound S-6999, on brown rats. Proceedings of the New Zealand Ecological Society 13: 40-43.

Brockie RE 1976. The role of wild animals in maintaining and transmitting Leptospirosis in New Zealand. Report to Department of Health, Wellington. $48 \mathrm{p}$.

Bull PC 1950a. Birds and mammals observed in the country between Lake Taupo and the Hauhangaroa Range. January 1-13, 1950. Report No. 9. Wellington, Animal Ecology Section, Department of Scientific and Industrial Research. $19 \mathrm{p}$.

Bull PC 1950b. Second report on Western Taupo area. Report No. 12. Wellington, Animal Ecology Section, Department of Scientific and Industrial Research. $16 \mathrm{p}$.

Bull PC 1952. Birds and Mammals of western Taupo. New Zealand Science Review 10: 91.

Bull PC 1954. Report on the visit of M.V. Holmlea to the
Auckland Islands, March 1954. Wellington, Animal Ecology Section, Department of Scientific and Industrial Research. In: Yaldwyn JC ed 1975. Preliminary results of the Auckland Islands Expedition 1972-1973. Wellington, Department of Lands and Survey. Pp. 326-328.

Chitty D, Southern HN 1954. Control of rats and mice. London, Clarendon Press.

Choate TS 1965a. Mammal and bird studies at Jacksons Bay. Science Record 15: 59-61.

Choate TS 1965b. Thompson Sound Expedition, January 18- February 6. Report to Fiordland National Park Board. File FNP 28. 1 p.

Choate TS 1967. Terrestrial vertebrates of the Monowai-Grebe River region. Science Record 17: 51-53.

Choate TS, Gibbs WA 1964. Small mammal investigations on Stewart Island. Science Record 14: 84-85.

Crook IG 1973. The tuatara, Sphenodon punctatus Gray, on islands with and without populations of the Polynesian rat, Rattus exulans (Peale). Proceedings of the New Zealand Ecological Society 20: 115-120.

Daniel MJ 1969. A survey of rats on Kapiti Island, New Zealand. New Zealand Journal of Science 12: 363-372.

Daniel MJ 1972. Bionomics of the ship rat (Rattus r. rattus) in a New Zealand indigenous forest. New Zealand Journal of Science 15: 313-341.

Daniel MJ 1973. Seasonal diet of the ship rat (Rattus $r$. rattus) in a lowland forest in New Zealand. Proceedings of the New Zealand Ecological Society 20: 21-30.

Daniel MJ 1978. Population ecology of ship and Norway rats in New Zealand. In: Dingwall PR, Atkinson IAE, Hay C eds 1978. The ecology and control of rodents in New Zealand nature reserves. Information Series No. 4. Wellington, New Zealand Department of Lands and Survey. Pp. 145-152.

Dingwall PR, Atkinson IAE, Hay C eds 1978. The ecology and control of rodents in New Zealand nature reserves. Information Series No.4. Wellington, New Zealand Department of Lands and Survey. 237 p.

Falla RA 1954. Report on the DSIR expedition to the Auckland Islands in HMNZS Tui, November 1954. Wellington, Dominion Museum. In: Yaldwyn JC ed 1975. Preliminary results of the Auckland Islands Expedition 1972-1973. Wellington, Department of Lands and Survey. Pp. 336-338.

Fleming CA, Bull PC 1988. Kazimierz Antoni z Granowa Wodzicki OBE, MAgrSc, PhD (Krakow), HonDSc (Victoria) 1900-1987. Proceedings of the Royal Society of New Zealand 116: 78-87.

Ford-Robertson JdeC, Bull PC 1966. Some parasites of the kiore, Rattus exulans, on Little Barrier Island and Hen Island, New Zealand. New Zealand Journal of Science 9: 221-224.

Gibson RN 1972. Metazoan parasites of rodents in New Zealand. Master of Science thesis. University of Canterbury, New Zealand. 146 p.

Greig JB 1886.Unpublished. Letter to the Secretary, Marine Department, Wellington from the master of the Government Schooner Kekeno regarding Auckland and other subantarctic islands, 11 October 1886. Wellington, New Zealand National Archives. 6 p.

Guthrie-Smith H 1936. Sorrows and joys of a New Zealand naturalist. Dunedin \& Wellington. AH and AW Reed. 252 p.

Henry R 1901. Resolution Island. Annual Report 1900-01. New Zealand Department of Lands and Survey. In: Appendix to the Journals of the House of Representatives C-1: 132-136. 
Imber MJ 1975. Petrels and predators. XII Bulletin of the International Council for Bird Preservation: 260-263.

Kean RI 1951. Some islands of the south: Resolution Island. Tararua 5: 29-31.

Marshall WH 1961. A note on the food habits of feral cats on Little Barrier Island, New Zealand. New Zealand Journal of Science 4: 822-824.

Meeson J 1885. The plague of rats in Nelson and Marlborough. Transactions of the New Zealand Institute 17: 199-207.

Merton DV 1968. Narrative of the Kermadec Islands Expedition, 10/10/66-9/1/67. Notornis 15: 3-22.

Merton DV 1970. Kermadec Islands Expedition reports: a general account of birdlife. Notornis 17:147-199.

Raynal FE 1875 . Wrecked on a reef; or twenty months among the Auckland Isles. London, Thomas Nelson and Sons. $350 \mathrm{p}$.

Reischek A 1888. Notes on rats. Transactions of the New Zealand Institute 20: 125-126.

Riney T, Watson JS, Bassett C, Turbott EG, Howard WE 1959. Lake Monk expedition. An ecological study in Southern Fiordland. Bulletin No. 135. Wellington, Department of Scientific and Industrial Research. 75 p.

Russell JC, Towns DR, Clout MN 2008. Review of rat invasion biology - implications for island biosecurity. Science for Conservation. Wellington, Department of Conservation. $53 \mathrm{p}$.

Rutland J 1890. On the habits of the New Zealand bush rat (Mus maorium). Transactions of the New Zealand Institute 22: $300-307$.

Sorensen JH 1949. Mus norvegicus on outlying islands of New Zealand. New Zealand Science review 7: 219-220.

Sorensen JH 1951. Wildlife in the subantarctic. Wellington, Whitcombe \& Tombs. 85 p.

Stead EF 1937. The Maori rat. Transactions of the Royal Society of New Zealand 66: 178-181.

Stolzenburg W 2011. Rat Island. London, Bloomsbury. 288 p.

Taylor DP 1984. The identification and detection of the rats in New Zealand and the eradication of ship rats on Tawhitinui Island. Dissertation for Diploma in Parks and Recreation. Canterbury, Lincoln College.

Taylor RH 1951. Observations of birds and mammals of Stewart Island, December 1950. Report No 15. Wellington, Animal Ecology Section, Department of Scientific and Industrial Research. 19 p.

Taylor RH 1970. Summary of studies carried out on Campbell and Antipodes Islands while with the University of Canterbury Antipodes Islands Expedition, 1969. File report. Lower Hutt, Animal Ecology Division, Department of Scientific and Industrial Research. 3 p.

Taylor RH 1975a. What limits kiore distribution in New Zealand? New Zealand Journal of Zoology 2: 473-477.

Taylor RH 1975b. The distribution and status of introduced mammals on the Auckland Islands, 1972-73. In: Yaldwyn JC ed Preliminary results of the Auckland Islands Expedition 1972-73. Wellington, New Zealand Department of Lands and Survey. Pp. 233-243.

Taylor RH 1978. Distribution and interactions of rodent species in New Zealand. In: Dingwall PR, Atkinson IAE, Hay C eds The ecology and control of rodents in New Zealand nature reserves. Information Series No. 4. Wellington, New Zealand Department of Lands and Survey. Pp. 135-140.

Taylor RH, Flux JEC 1965. Mammals. In: Host E ed Nelson Lakes National Park: a handbook for visitors. Nelson, Nelson Lakes National Park Board. Pp. 102-108.
Thomas BW 1975. Report on a visit to Breaksea Island, the 'Seal Islands' and the Gilbert Islands, Fiordland, December 1974. File report, Lower Hutt, Ecology Division, Department of Scientific and Industrial Research. 24 p.

Thomas BW, Taylor RH 2002. A history of ground-based rodent eradication techniques developed in New Zealand, 19591993. In: Veitch CR, Clout MN eds Turning the tide: the eradication of invasive species. Gland, Switzerland, IUCN SSC Invasive Species Specialist Group. Pp. 301-310.

Thomson GM 1922. The Naturalisation of animals and plants in New Zealand. Cambridge, Cambridge University Press. 632 p.

Watson JS 1951. The rat problem in Cyprus. Colonial Research Publication No. 9. London, Colonial Office. 66 p.

Watson JS 1953. Aliens in the forest: 3. The rat. Forest and Bird 109: 10-12.

Watson JS 1956. The present distribution of Rattus exulans (Peale) in New Zealand. New Zealand Journal of Science \& Technology 37: 560-570.

Watson JS 1959. Identification of rats and mice in New Zealand. New Zealand Journal of Agriculture 98: 365-368.

Watson JS 1961a. Mammals. In: Hamilton WM comp. Little Barrier Island (Hauturu). Bulletin 137. Wellington, New Zealand Department of Scientific and Industrial Research. Pp. 132-5.

Watson 1961b. Rats in New Zealand: a problem of interspecific competition. Proceedings of the Ninth Pacific Science Congress 19 (zoology): 15-16.

Whitaker AH 1973. Lizard populations on islands with and without Polynesian rats, Rattus exulans Peale. Proceedings of the New Zealand Ecological Society 20: 121-130.

Wilson PR, Karl BJ, Toft RJ, Beggs JR, Taylor RH 1998. The role of introduced predators and competitors in the decline of kaka (Nestor meridionalis) populations in New Zealand. Biological Conservation 83:175-185.

Wodzicki KA 1950. Introduced mammals of New Zealand. An ecological and economic survey. Bulletin No.98. Wellington, New Zealand Department of Scientific and Industrial Research. 255 p.

Wodzicki KA 1969. Preliminary report on damage to coconuts and on the ecology of the Polynesian rat ( $R$. exulans) in the Tokelau Islands. Proceedings of the New Zealand Ecological Society 16: 7-12.

Wodzicki KA, Bull PC 1951. The small mammals of the Caswell and George Sounds area. In: Poole AL comp. New Zealand- American Fiordland Expedition. Bulletin 103. Wellington, New Zealand Department of Scientific \& Industrial Research. Pp. 62-69.

Wodzicki KA, Robertson FH 1959. Birds with a note on the mammal Rattus exulans (Peale). In: Hamilton WM, Baumgart IL comps. White Island. Bulletin No.127. Wellington, New Zealand Department of Scientific and Industrial Research. Pp. 70-82.

Wodzicki KA, Taylor RH 1984. Distribution and status of the Polynesian rat Rattus exulans. Acta Zoologica Fennica 172: 99-101. 